\title{
The Effect Size of Fibromyalgia on PG-VAS in Rheumatoid Arthritis Patients. Adjustment Proposal in DAS28-ESR: Letter to the Editor regarding Challa, D.N.V., Crowson, C.S. \& Davis, J.M. Rheumatol Ther (2017) 4: 201. doi:10.1007/s40744-017-0063-5
}

David Vega-Morales (D) L Luis Ivan Lozano-Plata · Jorge Antonio Esquivel-Valerio

Received: May 28, 2017 / Published online: July 6, 2017

(c) The Author(s) 2017. This article is an open access publication

Keywords: Fibromyalgia; Rheumatoid arthritis

\section{Dear Editor,}

With great interest we read the article "The Patient Global Assessment of Disease Activity in Rheumatoid Arthritis: Identification of Underlying Latent Factors", by Challa et al [1]. The authors conducted an analytic, observational study in 70 rheumatoid arthritis (RA) patients. Data were evaluated using exploratory factor analysis to determine to what extent each factor influences the discordant Patient Global Assessment (PGA) of disease activity. Interestingly, we observed in the multivariate analysis the persistent influence of fibromyalgia syndrome in the PGA. The disease activity score in 28 joints with erythrocyte sedimentation rate

Enhanced content To view enhanced content for this article go to http://www.medengine.com/Redeem/ AC98F060497CDE96.

This letter refers to the original article available at doi:10.1007/s40744-017-0063-5.

D. Vega-Morales $(\varangle) \cdot$ L. I. Lozano-Plata .

J. A. Esquivel-Valerio

Servicio de Reumatología, Departamento de

Medicina Interna, Hospital Universitario “Dr. José

Eleuterio González", Universidad Autónoma de

Nuevo León, Avenida Gonzalitos 235 Norte,

Monterrey, Nuevo León, México

e-mail: drdavidvega@yahoo.com.mx
(DAS-ESR) is a method used to monitor disease activity in RA and is calculated using PGA.

We hypothesized that every non-RA musculoskeletal disorder could impact the PGA [2-5], as the patient no longer differentiates the pain source when various disorders coexist. We therefore, conducted an observational, descriptive cross-sectional study in 395 RA patients at a university hospital and analyzed the effect of fibromyalgia, knee osteoarthritis, and presence of tendinopathy (any) on the status of RA activity. Evaluation of the Health Assessment Questionnaire (HAQ) and Patient's Global assessment Visual Analogue Scale (PG-VAS) was included. We considered a VAS $>40$ to have clinical significance. We analyzed 395 patients, $390(91.1 \%)$ women, with a mean age of 51.1 (SD 12.7). Table 1 shows the clinical and activity characteristics of the RA patients with and without fibromyalgia. We found in the bivariate analysis that the presence of a VAS $>40$ was associated with a DAS28-ESR greater than 2.6 (OR 12.47, 5.2-29 95\% CI, $p=0.001$ ). Fibromyalgia was a predictor of PG-VAS $>40$ (OR 3.49, 1.72-7.08 95\% CI, $p=0.0001$ ). The other variables analyzed in the study did not have any influence on the DAS28-ESR in RA patients. As with the study by Challa et al., we observed an additive effect of fibromyalgia in the PG-VAS and therefore in the DAS28-ESR in patients with RA. The effect size of fibromyalgia diagnosis on the DAS28 was $27 \%$. We propose 
Table 1 Clinical, activity, and function characteristics of RA patients

\begin{tabular}{|c|c|c|c|}
\hline Variable & $\begin{array}{l}\text { With FM } \\
n=39\end{array}$ & $\begin{array}{l}\text { Without FM } \\
n=356\end{array}$ & $p$ value \\
\hline Age, years mean, SD & $55.5,6.8$ & $50.6,13.3$ & 0.02 \\
\hline DAS28-ESR median, IQR & $3.0,1.3$ & $3.1,1.4$ & 0.5 \\
\hline ESR mm/Hr median, IQR & $27.02,14.8$ & $29.1,12$ & 0.35 \\
\hline PG-VAS mm, mean, SD & $29.9,4.7$ & $22,1.2$ & 0.001 \\
\hline PG-VAS $>40 \mathrm{~mm} n, \%$ & $15,38.5$ & $54,15.2$ & 0.001 \\
\hline Presence of morning stiffness $n, \%$ & $17,43.6$ & $119,33.4$ & 0.2 \\
\hline Presence of night pain $n, \%$ & 39,100 & $336,94.4$ & 0.3 \\
\hline Functional class I $n, \%$ & $32,82.1$ & $270,75.8$ & 0.14 \\
\hline Knee osteoarthritis $n, \%$ & $11,28.2$ & $61,17.1$ & 0.08 \\
\hline Tendinopathy $n, \%$ & $4,10.3$ & $15,4.2$ & 0.094 \\
\hline \multicolumn{4}{|l|}{ HAQ-8 } \\
\hline Dress yourself, including tying shoelaces and doing buttons? $n, \%$ & $29,74.4$ & 217,61 & 0.1 \\
\hline Get in and out of the bed? $n, \%$ & $36,92.3$ & $337,94.7$ & 0.5 \\
\hline Lift a full cup or glass to your mouth? $n, \%$ & $36,92.3$ & 317,89 & 0.5 \\
\hline Wash and dry our entire body? $n, \%$ & $36,92.3$ & $336,94.4$ & 0.5 \\
\hline Bend down to pick up clothing from the floor? $n$, $\%$ & $34,87.2$ & $326,91.6$ & 0.35 \\
\hline Turn faucets/taps on and off? $n, \%$ & $38,97.4$ & $342,96.1$ & 0.67 \\
\hline Get in and out of a car? $n, \%$ & $36,92.3$ & $342,96.1$ & 0.27 \\
\hline Walk outdoors on flat ground? & $34,87.2$ & $320,89.9$ & 0.5 \\
\hline
\end{tabular}

Functional class I: without limitation to activities of daily living DAS28-ESR Disease Activity Score of 28 joints with ESR, PG-VAS patient's global assessment visual analogue scale, ESR erythrocyte sedimentation rate, $I Q R$ interquartile range, $H A Q$ health assessment questionnaire

to adjust the DAS28 when the PG-VAS is above 40 by multiplying by 0.73 to consider the effect of fibromyalgia in the evaluation. We believe this issue could be important in order to avoid overtreatment.

\section{ACKNOWLEDGEMENTS}

No funding or sponsorship was received for this study or publication of this article. All named authors meet the International Committee of Medical Journal Editors (ICMJE) criteria for authorship for this manuscript, take responsibility for the integrity of the work as a whole, and have given final approval for the version to be published.

Compliance with Ethics Guidelines. This article is based on previously conducted studies and does not involve any new studies of human or animal subjects.

Disclosures. David Vega-Morales, Luis Ivan Lozano-Plata, and Jorge Antonio Esquivel-Valerio have nothing to disclose. 
Open Access. This article is distributed under the terms of the Creative Commons Attribution-NonCommercial 4.0 International License (http://creativecommons.org/licenses/by-nc/4. $0 /$ ), which permits any noncommercial use, distribution, and reproduction in any medium, provided you give appropriate credit to the original author(s) and the source, provide a link to the Creative Commons license, and indicate if changes were made.

\section{REFERENCES}

1. Challa DNV, Crowson CS, Davis JM. Rheumatol Ther. 2017;4:201. doi:10.1007/s40744-017-0063-5.

2. Inanc N, Yilmaz-Oner S, Can M, Sokka T, Direskeneli $\mathrm{H}$. The role of depression, anxiety, fatigue, and fibromyalgia on the evaluation of the remission status in patients with rheumatoid arthritis. J Rheumatol. 2014;41(9):1755-60. doi:10.3899/jrheum.131171.

3. Roig Vilaseca D, Hoces Otero C. Effect of the coexistence of fibromyalgia in the DAS28 index in women with rheumatoid arthritis. Reumatol Clin. 2008;4(3):96-9. doi:10.1016/S1699-258X(08)71811-4.

4. Ton E, Bakker MF, Verstappen SM, Ter Borg EJ, Albada-Kuipers IA, Schenk Y, Veen MJ, Bijlsma JW, Jacobs JW, Utrecht Rheumatoid Arthritis Cohort Study Group. Look beyond the disease activity score of 28 joints (DAS28): tender points influence the DAS28 in patients with rheumatoid arthritis. J Rheumatol. 2012;39(1):22-7. doi:10.3899/jrheum. 110072.

5. Andersson ML, Svensson B, Bergman S. Chronic widespread pain in patients with rheumatoid arthritis and the relation between pain and disease activity measures over the first 5 years. J Rheumatol. 2013;40(12):1977-85. doi:10.3899/jrheum.130493. 